Вісник Харківського національного університету імені В.Н. Каразіна Серія "Математика, прикладна математика і механіка"

Том 89, 2019, с. $4-9$

УДК 519.216
Visnyk of V.N.Karazin Kharkiv National University Ser. "Mathematics, Applied Mathematics and Mechanics"

Vol. 89, 2019, p. 4-9

DOI: $10.26565 / 2221-5646-2019-89-01$

\title{
Convergence of random walks on double transitive group generated by its permutational character
}

\author{
A. L. Vyshnevetskiy \\ Kharkiv National Automobile and Highway University \\ 25 Yaroslava Mudrogo st., Kharkiv, 61002, Ukraine \\ alexwish50@gmail.com
}

Let $P$ be a probability on a finite group $G, U(g)=\frac{1}{|G|}$ the uniform probability on $G, P^{(n)}$ an $n$-fold convolution of $P$. Under well-known mild conditions, $P^{(n)} \rightarrow U$ if $n \rightarrow \infty$. A lot of estimates of the rate of the convergence are found in different norms. We consider the groups that have a double transitive presentation, and the probability $P$ that naturally arises in this presentation. An exact formula for rate of convergency for these groups for the norm $\|F\|=\sum_{g \in G}|F(g)|$, where $F(g)$ is a function on group $G$, is given.

Keywords: probability; finite group; convergency; convolution.

Вишневецький О.Л., Збіжність випадкових блукань на двічі транзитивній групі, породжених її підстановлювальним характером. Нехай $P$ - ймовірність на скінченній групі $G, U(g)=\frac{1}{|G|}-$ рівномірна ймовірність на $G, P^{(n)}-n$-кратна згортка функції $P$. Добре відомі умови, при яких $P^{(n)} \rightarrow U$ при $n \rightarrow \infty$. Оцінці швидкості цієї збіжності для різних норм присвячено багато робіт. Ми розглядаємо скінченні групи, які мають двічі транзитивне зображення підстановками, і ймовірність $P$, що природно виникає в цьому зображенні. В роботі дана точна формула швидкості збіжності для таких груп відносно норми $\|F\|=\sum_{g \in G}|F(g)|$, де $F(g)-$ функція на групі $G$.

Ключові слова: ймовірність; скінченна група; збіжність; згортка.

Вишневецкий А.Л., Сходимость случайных блужданий на дважды транзитивной группе, порожденных ее подстановочным характером. Пусть $P-$ вероятность на конечной группе $G, U(g)=\frac{1}{|G|}$ - равномерная вероятность на $G, P^{(n)}-n$-кратная свертка функции $P$. Хорошо известны условия, при которых $P^{(n)} \rightarrow U$ при $n \rightarrow \infty$. Оценке скорости этой сходимости для разных норм посвящено много работ. Мы рассматриваем конечные группы, имеющие дважды транзитивное представление подстановками, и вероятность $P$, которая естественно возникает в этом изображении. В работе дана точная формула скорости сходимости для таких групп относительно нормы $\|F\|=\sum_{g \in G}|F(g)|$, где $F(g)$ - функция на группе $G$.

Ключевые слова: вероятность; конечная группа; сходимость; свертка.

2010 Mathematics Subject Classification: 20D99; 60B15; 60B10.

(C) A. L. Vyshnevetskiy, 2019 
Let $P$ be a probability on a finite group $G, U(g)=\frac{1}{|G|}$ the uniform probability on $G, P^{(n)}-$ an $n$-fold convolution of $P$. Under well-known mild conditions, $P^{(n)} \rightarrow U$ if $n \rightarrow \infty$ (see [1]). A lot of estimates of the rate of the convergence are found in different norms ([2]). We consider the groups that have a double transitive presentation (by permutations), and the probability $P$ that naturally arises in this presentation.

A group $\mathrm{G}$ of permutations has its natural character which values equal to the number of points fixed by permutation. If $G$ is transitive, then (see [1] - [3])

$$
\frac{1}{|G|} \sum_{g \in G} \chi(g)=1
$$

so the function $P(g)=\frac{1}{|G|} \chi(g)$ is a probability on group $G$. The probability $P(g)$ naturally arises for any transitive permutation group $G$.

The function $P(g)$ is a class (or central) one, i.e. it has the same value on each class of conjugate elements of group $G$. There is a scalar product in a linear space $L(G)$ of class functions: for $F_{1}, F_{2} \in L(G)$

$$
\left(F_{1}, F_{2}\right)=\frac{1}{|G|} \sum_{g \in G} F_{1}(g) \bar{F}_{2}(g),
$$

where $\bar{F}$ is complex conjugate to a complex number $F$. Let $\operatorname{Irr}(G)=$ $\left\{\mathbf{1}_{G}, \chi_{1}, \ldots, \chi_{k}\right\}$ be the set of irreducible characters of group $G$, where $\mathbf{1}_{G}$ is a principal (or trivial) character. The set $\operatorname{Irr}(G)$ form an orthonormal basis of $L(G)$ with respect to the scalar product (1). So any class probability $P$ has decomposition in this basis

$$
P=\frac{1}{|G|} \mathbf{1}_{G}+m_{1} \chi_{1}+\ldots+m_{k} \chi_{k},
$$

for some complex numbers $m_{1}, \ldots, m_{k}$. Let $d_{j}=\operatorname{deg} \chi_{j}$ be the degree of the character $\chi_{j}$ and

$$
b_{j}=\frac{|G| m_{j}}{d_{j}} \quad(j=1, \ldots, k) .
$$

Lemma 1 For any natural number $n$

$$
P^{(n)}-U=\sum_{j=1}^{k} \frac{d_{j} b_{j}^{n}}{|G|} \chi_{j} .
$$

It was established in ([4], proof of theorem 3).

Let $G$ be a double transitive finite group, $\chi$ the abovementioned character of $G$, $d=\operatorname{deg} \chi$ its degree. As a character, $\chi$ is a class function. A permutation without fixed points is called regular. By definition, $\chi(g)=0$ if and only if permutation $g \in G$ is regular. 
Theorem $1\left\|P^{(n)}-U\right\|=\frac{2|A|}{(d-1)^{n-1}|G|}$, where $A$ is the set of regular permutations in $G$.

Proof. By Birnside theorem ([3] - [5]) $\chi=\mathbf{1}_{G}+\varphi, \varphi$ an irreducible character of $G, \operatorname{deg} \varphi=d-1$. Then (2) actually is

$$
P=\frac{1}{|G|} \mathbf{1}_{G}+\frac{1}{|G|} \varphi,
$$

i.e. in (2) $m_{1}=\frac{1}{|G|}, m_{2}=\ldots=m_{k}=0$, so in $(3) b_{1}=(d-1)^{-1}, b_{2}=\ldots=$ $b_{k}=0$. By the lemma above $P^{(n)}-U=M^{-1} \varphi$, where $M=(d-1)^{n-1}|G|$. As $\varphi=\chi-\mathbf{1}_{G}$ and $\chi(g)$ is a non-negative integer, then $\varphi(g) \geq 0$ for $g \in G \backslash A$, where $A=\{g \in G \mid \varphi(g)=-1\}$. As character $\varphi$ is irreducible, then $\sum_{g \in G} \varphi(g)=0$. For the considered norm

$$
\begin{aligned}
& \left\|P^{(n)}-U\right\|=\frac{1}{M} \sum_{g \in G}|\varphi(g)|=\frac{1}{M}\left(\sum_{g \in A} 1+\sum_{g \in G \backslash A} \varphi(g)\right)= \\
& =\frac{1}{M}\left(2 \sum_{g \in A} 1+\sum_{g \in G} \varphi(g)\right)=\frac{2|A|}{M}=\frac{2|A|}{(d-1)^{n-1}|G|} .
\end{aligned}
$$

Since $\varphi(g)=-1$ if and only if $\chi(g)=0$, then $A$ is the set of regular permutations in $G$.

Let us find the number of regular permutations of the following double transitive finite groups: the symmetric group $S_{d}$ of degree $d$, the alternating group $A_{d}$, the Zassenhaus groups and the Frobenius group of order $p(p-1)$ with Frobenius kernel of prime order $p$.

Definition ([3] p. 255). A group is said to be sharply k-transitive if it is ktransitive and the stabilizer of any $\mathrm{k}$ points is trivial. In case $k=2$ the group is called a Zassenhaus group ([5], p. 85). All sharply 2- and 3-transitive groups are known [3]. Let

$$
E_{d}=\sum_{r=0}^{d} \frac{(-1)^{r}}{r !} .
$$

Lemma 2 Let $G$ be a permutation group of degree $d$. The number $N_{0}$ of regular permutations in $G$ equals to:

a) $d ! E_{d}$, if $G=S_{d}$

b) $\frac{d !}{2} E_{d-2}+(-1)^{d-1}(d-1)$, if $G=A_{d}$;

c) $\frac{1}{2}(|G|-(d-1)(d-2))$, if $G$ is a Zassenhaus group;

d) $p-1$, if $G$ is a Frobenius group of order $p(p-1)$. 
Proof.

a) It is well-known problem about the number of derangements [7].

b) Since the group $A_{d}$ is sharply $(d-2)$-transitive, the number $N\left(i_{1}, \ldots, i_{r}\right)$ of its elements leaving definite $r$ points $i_{1}, \ldots, i_{r}$ fixed equals to

$$
N\left(i_{1}, \ldots, i_{r}\right)=\left\{\begin{array}{cc}
\frac{\left|A_{d}\right|(d-r) !}{d !}=\frac{(d-r) !}{2}, & 1 \leq r \leq d-2 \\
1, & d-1 \leq r \leq d
\end{array}\right.
$$

Therefore, the number of elements that leave arbitrary $r$ points fixed equals to

$$
C_{d}^{r} N\left(i_{1}, \ldots, i_{r}\right)=\left\{\begin{array}{cll}
\frac{(d-r) !}{2} \cdot \frac{d !}{r !(d-r !)}=\frac{d !}{2 r !}, & & 1 \leq r \leq d-2 \\
d & & r=d-1 \\
1, & r=d
\end{array}\right.
$$

If $r=0$, then $\frac{d !}{2 r !}=\frac{d !}{2}=\left|A_{d}\right|$. By the principle of inclusion-exclusion

$$
N_{0}=\frac{d !}{2} \sum_{r=0}^{d-2} \frac{(-1)^{r}}{r !}+(-1)^{d-1} d+(-1)^{d}=\frac{d !}{2} E_{d-2}+(-1)^{d-1}(d-1) .
$$

c) For Zassenhaus group

$$
N\left(i_{1}, \ldots, i_{r}\right)=\left\{\begin{array}{cl}
\frac{|G|(d-r) !}{d !}, & r=1,2 \\
1, & r \geq 3
\end{array}\right.
$$

As above, multiplying by $C_{d}^{r}$ and applying the principle of inclusion-exclusion, we get

$$
\begin{aligned}
& N_{0}=|G|-|G|+\frac{|G|}{2}-C_{d}^{8}+C_{d}^{4}-\ldots+(-1)^{d} C_{d}^{r}= \\
& =\frac{|G|}{2}-1+C_{d}^{1}-C_{d}^{2}+(-1)^{d}+(1-1)^{d}=\frac{1}{2}(|G|-(d-1)(d-2)) .
\end{aligned}
$$

d) As well known, a Frobenius group of order $p(p-1)$, with Frobenius kernel of prime order $p$, is a double transitive group. A stabilizer of any two points is trivial, so the group is sharply 2-transitive. All the regular permutations in $G$ are $(p-1)$ non-identity elements of its kernel. So $N_{0}=p-1$.

Corollary 1 The norm $\left\|P^{(n)}-U\right\|$ equals to:

$$
\begin{aligned}
& \text { 1) } \frac{2 E_{d}}{(d-1)^{n-1}} \text {, if } G=S_{d} \text {; } \\
& \text { 2) } \frac{2\left(E_{d-2}+\frac{2}{d !}(-1)^{d-1}(d-1)\right)}{(d-1)^{n-1}} \text {, if } G=A_{d} \text {; }
\end{aligned}
$$


3) $\frac{|G|-(d-1)(d-2)}{(d-1)^{n-1}|G|}$, if $G$ is a Zassenhaus group;

4) $\frac{2}{(p-1)^{n-1} p}$, if $G$ is a Frobenius group of order $p(p-1)$, with Frobenius

kernel of prime order $p$.

ORCID ID

A.L. Vyshnevetskiy (iD https://orcid.org/0000-0003-1757-0416

\section{REFERENCES}

1. P. Diaconis, Group Representations in Probability and Statistics. Institute of Mathematical Statistics, 1988. - 198 p.

2. L. Saloff-Coste, Random walks on finite groups. In Probability on Discrete Structures. H. Kesten (editor), Springer. - 2004. - P. 263-340.

3. D. S. Passman, Permutation groups, Benjamin, 1968. - 310 p.

4. M. Isaacs, Character theory of finite groups, AMS Chelsea. - 1976. - 303 p.

5. Ya. G. Berkovich, E. M. Zhmud, Characters of Finite Groups, part 2, Fields Institute Communications (v. 181), 1999. - 332 p.

6. A. L. Vyshnevetskiy. Random walks on finite groups with conjugate class probability: algebraic approach, Visnyk of V.N.Karazin Kharkiv National University, Ser. "Mathematics, Applied Mathematics and Mechanics", Vol. 86, 2017. - P. 4-9. (in Russian)

7. H. Ryser, Combinatorial mathematics, N. Y. - 1963. - 154 p.

Вишневецький О.Л., Збіжність випадкових блукань на двічі транзитивній групі, породжених її підстановлювальним характером. Нехай $P$ - ймовірність на скінченній групі $G, U(g)=\frac{1}{|G|}-$ рівномірна (або тривіальна) ймовірність на групі $G, P^{(n)}=P * \ldots * P-n$ - кратна згортка функції $P$. Добре відомі умови, при яких $P^{(n)} \rightarrow U$ при $n \rightarrow \infty$. Оцінці швидкості цієї збіжності для різних норм присвячено багато робіт. Ми розглядаємо скінченні групи, які мають двічі транзитивне зображення підстановками, і ймовірність, яка природно виникає в цьому зображенні. Ця ймовірність на кожному елементі групи $G$ пропорційна числу нерухомих (або стаціонарних) точок цього елемента, який розглядається як підстановка. Інакше кажучи, ця ймовірність $є$ характером зображення групи $G$ підстановками. Ймовірність називають класовою, якщо вона приймає однакові значення на кожному класі спряжених елементів групи, тобто $є$ функцією класу. Розглядувана ймовірність $€$ класовою, бо будь-який характер групи приймає однакові значення на спряжених елементах. Будь-якій ймовірності (i, взагалі, функції із значеннями у довільному кільці $K$ ) на групі $G$ можна зіставити елемент групової алгебри $K G$ цієї групи над цим кільцем $K$. Класовій ймовірності відповідає елемент центра цієї групової алгебри, тому класову ймовірність також називають центральною. На абелевій групі будь-яка ймовірність $є$ класовою (центральною). 
В роботі розглянута збіжність відносно норми $\|F\|=\sum_{g \in G}|F(g)|$, де $F(g)-$ функція на групі $G$. Для цієї норми дана точна формула (а не просто оцінка, як у переважній більшості робіт) швидкості збіжності згортки $P^{(n)}$ до тривіальної ймовірності $U(g)$ на групі $G$. Виявляється, що норма різниці $\left\|P^{(n)}-U\right\|$ визначається порядком групи $G$, ï̈ степенем, як групи підстановок, та числом регулярних підстановок у групі $G$. Регулярною називається підстановка, яка не має нерухомих точок. Розглянуто застосування вказаної формули у випадках, коли група $G \in$ симетричною, знакозмінною групою, групою Цассенхауза і групою Фробеніуса порядку $p(p-1)$ з ядром Фробеніуса порядку $p$ і доповненням порядку $p-1$ ( $p$ - просте число). Групою Цассенхауза називається двічі транзитивна група підстановок скінченної множини, в якій лише одинична підстановка залишає на місці більше двох елементів цієї множини.

Ключові слова: ймовірність; скінченна група; збіжність; згортка.

A. L. Vyshnevetskiy, Convergence of random walks on double transitive group generated by its permutational character. Let $P$ be a probability on a finite group $G, U(g)=\frac{1}{|G|}$ the uniform (trivial) probability on the group $G, P^{(n)}=P * \ldots * P$ an $n$-fold convolution of $P$. A lot of estimates of the rate of the convergence $P^{(n)} \rightarrow U$ are found in different norms. It is well known conditions under which $P^{(n)} \rightarrow U$ if $n \rightarrow \infty$. Many papers are devoted to estimating the rate of this convergence for different norms. We consider finite groups that have a double transitive representation by substitutions and the probability that naturally arises in this image. This probability on each element of the group is proportional to the number of fixed (or stationary) points of this element, which is considered as a substitution. In other words, this probability is a character of the substitution representation of the group. A probability is called class if it takes the same values on each class of conjugate elements of a group, that is, it is a function of the class. The considered probability is class because any character of a group takes on the same values on conjugate elements. Any probability (and, in general, functions with values in an arbitrary ring) on a group can be associated with an element of the group algebra of this group over this ring. The class probability corresponds to an element of the center of this group algebra; that is why the class probability is also called central. On an abelian group, any probability is class (central).

In the paper convergence with respect to the norm $\|F\|=\sum_{g \in G}|F(g)|$, where $F(g)$ is a function on group $G$, is considered. For the norm an exact formula not estimate only, as usual for rate of convergence of convolution $P^{(n)} \rightarrow U$ is given. It turns out that the norm of the difference $\left\|P^{(n)}-U\right\|$ is determined by the order of the group, degree the group as a substitution group, and the number of regular substitutions in the group. A substitution is called regular if it has no fixed points. Special cases are considered the symmetric group, the alternating group, the Zassenhaus group, and the Frobenius group of order $p(p-1)$ with the Frobenius core of order $p$ ( $p$ is a prime number). A Zassenhaus group is a double transitive substitution group of a finite set in which only a trivial substitution leaves more than two elements of this set fixed.

Keywords: probability; finite group; convergency; convolution.

Article history: Received: 11 March 2019;

Accepted: 03 April 2019. 